\title{
Gender Bias in Manggarai Languages East Nusa Tenggara: A Sociolinguistic Study
}

\author{
Yuliana Jetia Moon \\ \{yulianajetiamoon@gmail.com\} \\ Unika Santu Paulus Ruteng, Indonesia
}

\begin{abstract}
Language is a cultural product. People have created language to describe the existence and position of a person within society, including to a woman. Within a patriarchal community where a man's position is higher than a woman's, people tend to have gender-biased language. This study analyzed the aspects of gender-biased within the Manggarai language. The language belongs to the people of Manggarai at East Nusa Tenggara, Eastern Indonesia. The community is a patriarchal one. This study explored the symptoms of language diversity used for women who are gender-biased. This research employed a qualitative descriptive study with an ethnographic as its primary method. It used observation and interviews as data collection methods. This study found that there has been various gender-biased languages using to position a woman lower and more marginalized than a man. People might use and find those languages in daily communication, in satire language, terms, in figurative language in the form of go'étgo'et, or even within the ritual-religious form. The biased-gender language has become one of reasons of gender inequality in the community.
\end{abstract}

Keywords: gender; bias; language; Manggarai

\section{Introduction}

Manggarai is located at Flores, Eastern Indonesia. Studies about this community have pointed out that the Manggarai community is a patriarchal society. The position of a man is higher and more important than a woman (Lon \& Widyawati, 2020). The Manggarai consider a man as an autonomous person. He is the leader and the owner of his clan (Lon \& Widyawati, 2017). Meanwhile, a woman is a dependent person. Before marriage, she belongs to his father, and after marriage, she belongs to her husband (Lon \& Widyawati, 2018).

The different title between a man and a woman has been declared very early when he or she was born. When a mother would give birth, the husband and some of his relatives gathered outside the maternity room. Once they heard the baby's crying, they would ask, "Ata one ko ata peang?" which means "outsiders or insiders?" So, since a Manggarai baby was born into the world, he has been greeted with a language that determines his identity in the social system, (Widyawati,2020) [4]. "Outsider" is a term that refers to a baby girl which indicates that she is someone who has to leave the house, has no right to inheritance, and is not a successor.

Meanwhile, 'insider' refers to a male baby which means the opposite, namely as a person who lives in the house, have the right to inheritance, and is a descendant of the offspring. The language is a cultural product of the Manggarai people. Language is a reflection of the way the 
people think that created it. The way people think will have an impact on their social attitudes. The social attitudes towards women and men in a patrilineal society are still very different. [5] Sumarsono (2014: 113) states that language diversity based on gender arises because language as a social symptom is closely related to social attitudes.

In reality, humans are created to be different from each other, women are different from men. The language system also differentiates between men and women. The most common, for example, the greeting system in each language, which generally distinguishes between men and women. But in reality, there are also varieties of language, which are not just a language system that differentiates men and women, but also contain values and social values in them. The differences in the variety of languages used for men and women distinguish them in their social roles, their position in society, and the rules that bind them.

The content of social roles between women and men in language can be seen in the customary leadership system of the Manggarai community. In Manggarai society there is no variety of languages provided for women leaders. All types, such as tu'a golo 'village leader', tu'a teno 'land distribution leader', and tu'a gendang 'traditional house leader' are reserved for men only. 'The word tu'a means leader and male. Unlike the case with the word's regent, governor, village head, it can refer to male or female leaders.

Language and gender are very interesting issues to address. The object of sociolinguistic study is a language with society. Language-speaking societies certainly have certain cultures and perspectives, including perspectives on gender equality. So, language as an object of sociolinguistic study can certainly provide this description. [6] Schilling (2011:218) "The relationship between gender and language has long been a matter of great interest for the general public as well as researchers in fields ranging from cultural studies to psychology to neurology to, of course, sociolinguistics."

[7] Baxter (2011:331) "Folk-linguistic evidence has long portrayed the language of women and man to be different". In the sociolinguistic view, there is no homogeneous society, so the language of the people is different. However, sometimes the differences are too strong so that they can fulfill according to the basis of social class including gender.[8] Guy (2011:159) "In all human societies, individual will differ from one other in the way they speak. Some of these differences are idiosyncratic, but others are systematically associated with particular groups of people. The most obvious of these are associated with sex and development: women speak differently from men, and children from adults. These two dimensions of social variation in language are in part biologically determined (e.g differences in laryngeal size producing different pitch levels for adult men and women), but in most societies, they go beyond this to become conventional and socially symbolic."

Gender bias can be learned through language. Language can provide a clear picture of the perspective, mindset, and ideology of society about women. In English people greet in the order of 'ladies and gentleman' while in Indonesian people greet in the order of male than female, like 'brother and sister'. Does this chanting sequence give an idea of who came first? The history of the gender equality movement was first fought for in western countries so that the issue is not new anymore. The opposite happened in Indonesia; the issue of gender equality is still the most popular because in modern times women have not played many roles in society. [9] Sylvia (2011: 4) reveals that gender inequality or the subordinate placement of women that occurs in society does not only occur today but has been established in local communities in the past. In this case, it can be interpreted as an appreciation of rigid customs.

Furthermore, Sylvia explained that after the condition of the local community places women as subordinates, there will be subordination to the position of women in the system of economic, political, and social roles. And in fact, this happens in our society, society builds a 
system that places men before women so that this is reflected in the language system it uses. Do these symptoms appear in the Manggarai community? Then these symptoms can be examined through language.

From a cultural point of view, the Manggrai community is a patrilineal society. Patrilineal society is a society that follows the paternal lineage. The question is, as a patrilineal society, where do Manggarai people position women. [10] Hall (2012:31) When we use language, we do so as individuals with social histories. Our histories are defined in part by our membership in a range of social groups into which we are born such as gender, social class, religion, and race. For example, we are born as female or male and into a distinct income level that defines us as poor, middle class, or well to do.

\section{Method}

This type of research is qualitative research. Sources of data in this study are Manggarai language speakers who live in Manggarai Regency. The research data is Manggarai language speech which shows language diversity based on gender. The data are then narrowed down to utterances that show gender bias in Manggarai society. The data collection technique was done by interview and observation. The data analysis technique was carried out by collecting research sample data in the form of Manggarai language speech which shows language diversity based on gender; the sample is then synthesized into data showing gender bias in the variety of Manggarai languages; data are grouped based on data similarity; the data were analyzed and conclusions were drawn based on the research questions.

\section{Result and Discussion}

In the Manggarai language system, people refer to women by the word ine wai. The word ine wai consists of two words, namely ine 'mama' wai 'married'; "woman." Based on the meaning of this word, the word ine wai can contain several meanings at once, namely, a woman is a mother; women are getting married, or after marriage, a woman will become a mother. Meanwhile, the word for the boy is ata rona. The word ata 'person' and the word rona 'husband'. Then the word ata rona can manifest a husband. From this meaning, there is a very different estuary of social roles. Women have wider roles and heavier responsibilities. The role of women is not only as wives but also as mothers. So, it can be said that the meaning of the words ine wai and ata rona contains a very different philosophy.

In every society, some words are synonymous with women in a negative connotation. These words take the form of satire and are usually very popular. In Indonesian, there are very popular words, for example, pelakor "taking someone's husband", sundal "immoral woman", or simpanan "illegitimate wife". A similar term is unpopular with men. As if those words were only for women. This negative behavior is not only done by women but also by men. In the Manggarai language, there are similarities in words, for example, tunang which means spinster.

However, this diction has a broader meaning than the spinster. If someone is called a tunang, it means that she has no hope of the future, she is considered inferior and can be made a joke for herself. In this context, implied the view of society about women, that women must marry, women should not marry late, and the existence of women is very much determined by 
men. However, a different perspective occurs in men. There is no similar term in men. Thus, men are allowed to marry at old age and the existence of men is not entirely determined by women. Apart from the word tunang, a similar word is a word pa'u pacu which means wrinkled cheeks. Physically, when a woman is old, her cheeks will wrinkle. This term has a negative meaning, such as ridicule for a woman who has passed the age limit for marriage. The spinster was no longer physically attractive, her skin was wrinkled, and as a result, she did not have a husband.

Mejok deko-ngguing wuli- lelak medak-momang nggotak. This term is used by people to insinuate women who are close to many men or women who do not refuse to be invited by men. This term is even used by many parents to advise their daughters. The meaning of the words above is very gender-biased. These words relate to animals, such as buffalo, horse, pig, or other animals. Mejok means a tame animal. If the word mejok is combined with the word deko, then the word is tame pants. The word ngguing wuli means that if stroked it will respond. Lelak medak means quickly raising your head. And momang nggotak means that he likes the sound of a horse's footsteps or likes to be ridden. So, the terms related to these animals are attached to women who are easily invited by men. Like an animal, if caressed it will be tame, respond quickly to caresses, when stroked it will prance and be happy to be ridden.

Another term that is also used is jamal. Around the 2000s this term was very popular. At that time, many Manggarai people migrated to Malaysia. The term jamal stands for Malaysian widow. However, in its development, this term has a negative charge, because what Jamal said was lonely women because their husbands left them to wander. Even though jamal is an acronym for Indonesian, in reality, this diction is used with sentences in the Manggarai language. So, if a woman is abandoned by her husband, she is also looked down upon by society. So, this word has a gender bias.

Other popular terms are ata peang and ata one. Since childhood, Manggarai women have been given status based on their gender. When the baby is born, someone outside the house will ask, "Ata peang ko ata one?" which means "Is it a baby born from an outsider or an insider?" Baby girls are called outsiders or ata peang. An outsider is a person who leaves or leaves the house, is not a successor, and does not receive an inheritance right. While a baby boy is an insider or ata one, which means that he will continue the offspring and become the heir, (Lon dan Widyawati, 2019)11. So, the vocabulary used has shown that the position of men is considered higher than that of women.

Another term that denotes a subordinate position for women is the word wela. Consider the following conversation. Person A asked, "Hitu waúd ko?" and B replied, "Toe puúd ise, wela kali ise." The meaning of the conversation can be translated as follows. A: "Is that the offspring?" and B: "No, that's not the tree, they're just the flowers." The meaning of the answer from person $\mathrm{B}$ is, he and his descendants are not core descendants, only part of that lineage (brothers). Male descendants are likened to diction puú or tree trunks. Meanwhile, female descendants are likened to wela or flowers. The ideology implied in it is that men are the essence of an offspring while women are only part of men.

In Indonesian, there is the greeting for father which is respected for men and there is the equivalent word for mother for women. So, the words head of the village, teacher, the director can be preceded by the words father or mother, for example, bapak guru and ibu guru. In this case, the role of women in society is recognized because there is a vocabulary for this. In the Manggarai language, the vocabulary is only provided for men, namely the word kraeng or kraengtua which means master or the elder. Although the word kraeng has experienced the meaning of amelioration, the word kraeng is synonymous with greetings that show respect for 
elder men, community leaders, or simply respect without any reason as long as he is a man. However, in the Manggarai language, there is no equivalent word for woman, even though she is an accomplished woman, is elder, or has a high social status.

Even in the history of Manggarai beliefs before converting to Catholicism, it is stated that the name of the God being worshiped is Mori Kraeng 'belonging to the master' which contextually means God. The word kraeng attached to the word mori means that God is a man. In the oral literary culture of the Manggarai people, there are expressions, which are called go'et. Go'et is figurative language. These go'et sentences contain meanings related to the philosophy of life of the Manggarai people. There are examples of go'et which also relate to the positioning of women.

Ame rinding mane, Ine rinding wie

Father protects in the afternoon, the mother protects the night

In this go'et, the role between men and women is implied when they become father and mother. The prediction mane can be light, morning to evening. During the day people work for a living. The phrase 'father is the protector of the day' can state that the father is the backbone of the wider family outside the home. Meanwhile, the role of women as protectors at night. The definition of wie or night reserved for mothers can be broadened to mean cold, dark, and sleep. So, a mother is given the role of giving warmth (from cold), eliminating fear (from the dark), and giving peace (while sleeping). The role of the mother is limited to a smaller area. However, of course in reality, since a long time ago the role of mother was not only a source of love or warmth, mother also played a role in a wider area. He can also earn a living like a father. So, it can be said, the variety of languages in this go'et is gender-biased.

Kole okan mokang, kole ramin laki

Back to the cage of the female, back to the forest of the male

This goét explains the different spaces for movement between men and women. This go'et deals with divorced couples. It is said that when divorced, the woman returns to the cage "oka" and the man goes to the jungle "ramin." Oka is a narrow cage, the space for women is likened to a narrow cage, kept, and just waiting. On the other hand, the man's place is a vast forest and a free life. So, this goét is also gendered biased.

Lalong bakok du lakom, lalong rombeng du kolem.

White rooster when leaving, colored rooster when coming home.

In the Manggarai community, there are traditional events related to a certain event. One of them is the wuát wai event. The event is related to releasing someone to wander. In this event there is a go'et, lalong bakok du lakom, lalong rombeng du kolem. The implied meaning in this go'et is that when someone wanders, he does not have anything which is compared to the diction of lalong bakok or white rooster and he is expected to have something when he returns which is likened to the diction of lalong rombeng or rooster with color. The word that is gender-biased is the word lalong. Lalong means male. Male means brave. In more depth, there is an ideology that is held that men are higher in rank. Humans are expected to be handsome like a man, whether male or female, he must be strong like a rooster. Even though it is a girl who wants to wander, she is still prayed for like a rooster. 
Pase sapu kole mbaru, pake panggal kole tana

Going home using a headband, returning home using a traditional headdress

Destar and panggal are attributes that are used by men on the head. Destar and panggal are used by caci dancers. The caci dance is a traditional Manggarai dance as a symbol of masculinity. The meaning of go'ét is if a person who goes overseas, let him return home when he has to show success. Success is represented by the prowess of using a destar and panggal.

Oke rona ngoeng, dián lelo ilang

Throw away dear husband, happy to see weeds

This goétmeans about women who have an affair. Go'et, oke rona ngoeng, dián lelo ilang is go'et which means a woman who throws her husband away because she sees weeds. There is also a similar go'et for the mistress of royalty or kings in ancient times, namely ine wina loce kumbu de kraeng. The meaning is that a woman who makes herself an illegitimate wife is like a man's heating mat.

\section{Kemu ngencung, nggepo kebor}

Hugging the morning pounder, hugging the spoon.

Go'et which is used for women who come to men's houses without customary procedures. This woman is termed go'et, kemu ngencung, nggepo kebor. The meaning of this go'et is very deep. Kemu ngencung means hugging the rice mash. Nggepo kebor means hugging a spoonful of rice. So, a woman who enters a man's house without going through traditional procedures is likened to a woman who with her desire comes to hug kitchen utensils.

\section{Ine wai roto tong, beka lenga}

Women are like baskets that lookup and open baskets

Go'et means immoral women. A prostitute woman is like a roto tong or shellfish that is always ready to hold whatever is put in. An immoral woman is likened to a beka lenga or a basket that is open and can be seen whatever its contents. Roto and beka are household items that are always used by women in their daily life. So, this goet likens women to baskets. The go'et is of course gender-biased because men as prostitutes do not get the same term.

\section{Conclusion}

This study aims to describe the gender bias in the variety of Manggarai languages. Based on the research findings, it can be concluded that in the Manggarai language various languages are gender-biased. This can be found in the everyday language of the Manggarai people, such as satire, terms, and figurative language in the form of go'ét-go'et. This research is still seen from one point of view. Research from different perspectives can of course provide different data, for example, the variety of Manggarai languages which shows the respect of the 
Manggarai community for women. So, it can be said that this research is still limited and can be developed from a different point of view.

\section{References}

[1] Lon, Y. S., \& Widyawati, F. Mbaru Gendang, Rumah Adat Manggarai, Flores: Eksistensi, Sejarah, dan Transformasinya. PT Kanisius

[2] Lon, Y. S., \& Widyawati, F. (2017). Lingkaran Kekerasan Terhadap Anak Dalam masyarakat Manggarai. Jurnal Pendidikan dan Kebudayaan Missio, 9(1), 12-20; Lon, Y. (2016). Children in Manggarai Culture: Understanding the Root of Violence Against Children in Manggarai.

[3] Lon, Y. S., \& Widyawati, F. Bride-Wealth: Is There Respect for Women in Manggarai, Eastern Indonesia?. Jurnal Humaniora, 30(3), 271-278. DOI: 10.22146/jh.v30i3.29216

[4] Widyawati, F. (2020). When Love And Faith Collide: Women's Conversion to Husband's Religion in Flores. Journal Of Indonesian Islam, 14(2), 335-358.

[5] Sumarsono. 2014. Sosiolinguistik. Yogyakarta: Sabda

[6] Schilling, Natalie. 2011. Language, Gender, and Sexuality (The Cambridge Handbook of Sociolinguistics). New York: Cambridge University Press

[7] Baxter, Judith. 2011. Gender (The Routledge Handbook of Applied Linguistics). London and New York: Routledge

[8] Guy, Gregory R. 2011. Language, Social Class, and Status (The Cambridge Handbook of Sociolinguistics). New York: Cambridge University Press

[9] Sylvia, Walby. 2011. The Impact of Feminism on Sociology. Sociological Research Online, 16(3), $1-10$.

[10] Hall, Joan Kelly. 2012. Teaching and Researching Language and Culture. England: Longman is an imprint of PEARSON

[11] Lon, Y. S., \& Widyawati, F. (2020, June). Women and Inheritance Rights in Manggarai, Eastern Indonesia: A Fight for Gender Equality. In ISLLCE 2019: Proceedings of the First International Seminar on Languare, Literature, Culture and Education, ISLLCE, 15-16 November 2019, Kendari, Indonesia (p. 153). European Alliance for Innovation. 